\title{
Is Bodyweight-Based Dosing Truly Better Than Flat Dosing for Panitumumab? [Response to Letter]
}

This article was published in the following Dove Press journal:

Clinical Pharmacology: Advances and Applications

\author{
Michael Z Liao' \\ Johannes Kast ${ }^{\prime}$ \\ Marloes Berkhout ${ }^{2}$ \\ Hans Prenen ${ }^{3}$ \\ Sandeep Dutta ${ }^{4}$ \\ Vijay V Upreti $\mathbb{B D}^{\prime}$ \\ 'Clinical Pharmacology, Modeling \& \\ Simulation, Amgen Inc., South San \\ Francisco, CA, USA; ${ }^{2}$ Amgen B.V., Breda, \\ the Netherlands; ${ }^{3}$ Antwerp University \\ Hospital, Edegem, Belgium; ${ }^{4}$ Clinical \\ Pharmacology, Modeling \& Simulation, \\ Amgen Inc., Thousand Oaks, CA, USA
}

Correspondence: Vijay V Upreti

Clinical Pharmacology, Modeling \& Simulation, Amgen, II 20 Veterans

Boulevard, South San Francisco, CA 94080, USA

Email vupreti@amgen.com

\section{Dear editor}

Thank you for the opportunity to respond to the letter by Dr. Hendrikx and colleagues.

We wish to thank Dr. Hendrikx and colleagues for their interest in our recent publication by Liao et $\mathrm{al}^{1}$ and their comments about the optimal dosing regimen for panitumumab.

The body weight-based dosing, $6 \mathrm{mg} / \mathrm{kg}$ once every two-week (Q2W) regimen, for panitumumab as an optimal dosing regimen is fully supported by clinical study data and pharmacokinetic modeling and simulations. ${ }^{2}$

Based on our analysis of 352 patients from 3 studies, body weight impacted panitumumab exposure. Observed $\mathrm{C}_{\max }$ and $\mathrm{C}_{\min }$ increased with increasing body weight after administration of panitumumab $6 \mathrm{mg} / \mathrm{kg}$. In addition, a population pharmacokinetic model of panitumumab developed based on 1200 patients and 14 clinical studies identified body weight as a significant covariate for the greatest contribution of interpatient variability. ${ }^{3}$ Consistent with observed data, model-based simulation demonstrated that the weight-based dose $(6 \mathrm{mg} / \mathrm{kg})$ led to substantially lower variability in panitumumab exposure across the range of body weights than fixed dosing (480 mg), supporting that a body weight-based approach leads to lower variability in drug exposure across patients. Importantly, the scientific justification of $6 \mathrm{mg} / \mathrm{kg}$ Q2W regimen for panitumumab was accepted and approved by global regulatory agencies in the USA, European Union, Japan, and over 70 countries in total.

The body weight-based dosing of $6 \mathrm{mg} / \mathrm{kg}$ Q2W regimen for panitumumab was based on thorough pharmacokinetic analysis aimed to reduce interpatient variability in drug exposure with the goal to optimize dosing and improve patient efficacy and safety, as recommended by the FDA. ${ }^{4}$ Fixed doses of panitumumab are not FDA approved and suboptimal dosing may impede efficacy and safety. It is now well understood that not all monoclonal antibody (mAb)-based therapies should be administered as flat dose regimen, nor should all be dosed based on body size as previously thought. Some mAb demonstrate clinically relevant impact of body size on exposure whereas others do not. The dosing rationale of $\mathrm{mAb}$ should therefore always be data-driven and based on the totality of the scientific evidence.

\section{Disclosure}

Michael Z. Liao, Johannes Kast, Sandeep Dutta and Vijay V. Upreti are employees of and stockholders in Amgen. Marloes Berkhout is an employee of Amgen B. V. and has restricted shares in Amgen. Hans Prenen has received honoraria and/or 
travel grants from Amgen, Bayer, Ipsen, Lilly, Merck, Novartis, Pfizer, Roche, Sanofi, Terumo, and Vifor pharma. The authors report no other potential conflicts for this communication.

\section{References}

1. Liao MZ, Berkhout M, Prenen H, Dutta S, Upreti VV. Dose regimen rationale for panitumumab in cancer patients: to be based on body weight or not. Clin Pharmacol. 2020;12:109-114. PMID: 32801947; PMCID: PMC7406372. doi:10.2147/CPAA.S262949
2. Vectibix ${ }^{\circledR}$ (panitumumab). Full Prescribing Information. Thousand Oaks, CA: Amgen Inc; 2017.

3. Ma P, Yang BB, Wang YM, et al. Population pharmacokinetic analysis of panitumumab in patients with advanced solid tumors. $J$ Clin Pharmacol. 2009;49(10):1142-1156. doi:10.1177/0091270009344 989

4. Zhao L, Ren TH, Wang DD. Clinical pharmacology considerations in biologics development. Acta Pharmacol Sin. 2012;33(11):133 9-1347. doi:10.1038/aps.2012.51

Dove Medical Press encourages responsible, free and frank academic debate. The content of the Clinical Pharmacology: Advances and Applications 'letters to the editor' section does not necessarily represent the views of Dove Medical Press, its officers, agents, employees, related entities or the Clinical Pharmacology: Advances and Applications editors. While all reasonable steps have been taken to confirm the content of each letter, Dove Medical Press accepts no liability in respect of the content of any letter, nor is it responsible for the content and accuracy of any letter to the editor.

Clinical Pharmacology: Advances and Applications

Dovepress

\section{Publish your work in this journal}

Clinical Pharmacology: Advances and Applications is an international, peer-reviewed, open access journal publishing original research, reports, reviews and commentaries on all areas of drug experience in humans. The manuscript management system is completely online and includes a very quick and fair peer-review system, which is all easy to use. Visit http://www.dovepress.com/testimonials.php to read real quotes from published authors. 